\title{
The association Veronico-Mimuletum guttati Niemann 1965 in Pomerania
}

\section{Zbigniew Sobisz*, Zbigniew Osadowski \& Mariola Truchan}

Department of Botany and Nature Protection, Pomeranian University, Arciszewskiego 22b, 76-200 Słupsk, Poland

* corresponding author (e-mail: sobisz@apsl.edu.pl)

\begin{abstract}
Veronico-Mimuletum guttati, a poorly known association of species-rich helophyte beds communities was characterized based on 21 phytosociological relevés. Its new 14 localities in Pomerania and floristic differentiation in Central Europe are presented. New subassociations of the Veronico-Mimuletum guttati cardaminetosum amarae have been distinguished on the basis of differing floristic composition. It is further differentiated into two syntaxa: spring variant noted in spring areas and typical variant noted in banks of rivers, ditches and water-logged meadows.
\end{abstract}

Key words: Mimulus guttatus, Sparganio-Glycerion fluitantis, new syntaxa, ATPOL grid, Pomerania, Central Europa

\section{Introduction}

Monkeyflower (Mimulus guttatus DC.) is native of the western North America from Alaska to northern Mexico, with an eastern limit in Montana and South Dakota (Meusel et al. 1978; Hultén \& Fries 1986). The spread of Mimulus guttatus in Europe started in the $19^{\text {th }}$ century (Oberdorfer 2001). In Poland, the first report dates from 1824 (Kowary) in the Sudety Mts. (Lohmeyer \& Sukopp 1992). The oldest registered date of the occurrence of this species in Europe is 1812 in Great Britain, next 1814 - Scotland and 1824 - Germany (Slavík 2000). At the same period, it was recorded in Pomerania; it was seen in 1874 in Koszalin (Holzfuß 1937), in 1922 in Damnica (Misiewicz 1977) and in 1929 in Wrzeście - (leg. F. Marquardt, Herbarium SLTC = acronym: SLUPSK TEACHERS ACADEMY). The history of dispersion of this species was investigated by Piękoś (1972) who recorded the occurrence of this species at 112 localities. Nowadays, it is present most often in Lower Silesia and Pomerania. Until now, it has been recorded in 326 localities in 128 ATPOL squares (Tokarska-Guzik 2005). Monkeyflower is one of the species that uses banks of rivers, streams and lakes as well as ditches; it is rare in pastures and ruderal habitats. The aim of the present studies was to investigate distri- bution, differentiation and phytosociological characteristics of the Veronico-Mimuletum guttati Niemann 1965 community.

\section{Material and methods}

Field studies were carried out during the vegetative seasons of 2005-2014 in Central Pomerania which is the area between the river Łeba to the east and the river Parsęta to the west. According to Kondracki (2004), it is the eastern part of Koszalin Coastland. Phytosociological relevés were collected using the Braun-Blanquet method (Braun-Blanquet 1951; Pawłowski 1977). The classification and nomenclature of syntaxa was adopted after Ratyńska et al. (2010), the nomenclature of the vascular plants - after Mirek et al. (2002) and of the mosses - after Ochyra et al. (2003). Each stand was identified in a network of ATPOL squares (Zając 1978): (1) BA88 - Pomiłowo, (2) BA97 - Paprotki, (3) BA98 - Łętowo, (4) BB22 - Sińce, (5) BB41 - Łąkowo, (6) BB44 - Ogartowo, (7) BB54 - Popielewko, (8) CA43 - Charbrowo, (9) CA51 - Smołdzino, (10) CA51 - Stojcino, (11) CA70 - Leszczyce, (12) CA72 - Łupawa, (13) CA82 - Gogolewko, (14) CB00 - Broczyna (Fig. 1).

All phytosociological relevés were recorded in TURBOVEG database, and subsequently were grouped, 


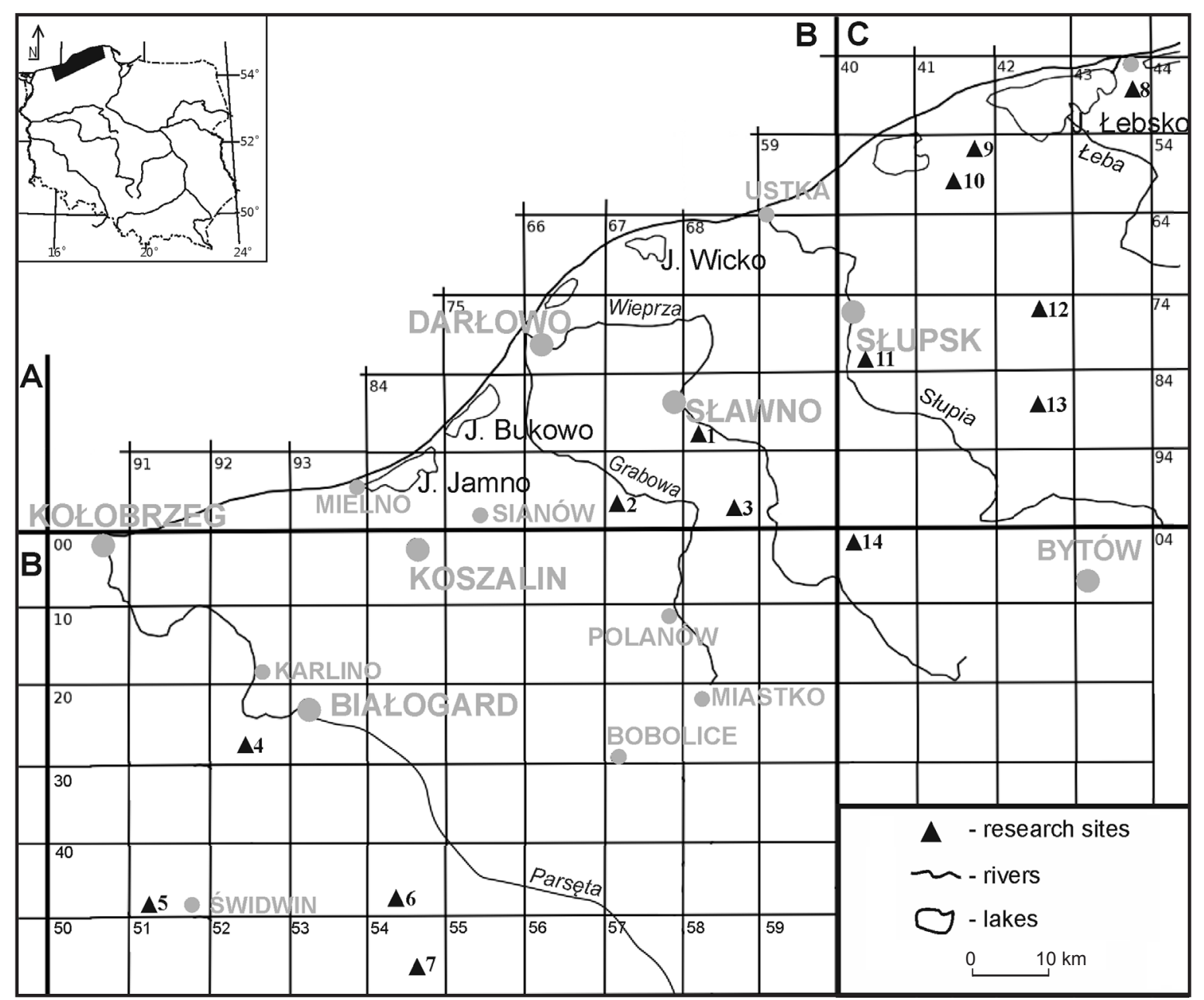

Fig. 1. Distribution of Mimulus guttatus in the ATPOL grid of the Central Pomerania

Explanations: a - research sites, b - rivers, c - lakes; 1-14 - localities of Mimulus guttatus (see in text)

making introductory evaluation of similarities by means of TWINSPAN software (Hennekens \& Schaminée 2001). The set of 21 was analyzed to the $6^{\text {th }}$ level after previous transformation of 7 degree Braun-Blanquet's scale into the order scale, adopting the following values: $\mathrm{r}-1,+-2,1-3,2-5,3-7,4-8,5-9$. Plant communities were classified by means of NCLAS software from SYNTAX

Table 1. Abundance codes according to the Braun-Blanquet scale, with corresponding values of average coverage

\begin{tabular}{cc}
\hline Abundance code & Average coverage [\%] \\
\hline $\mathrm{r}$ & 0.1 \\
+ & 0.5 \\
1 & 5.0 \\
$2 \mathrm{~m}$ & 7.0 \\
$2 \mathrm{a}$ & 10.0 \\
$2 \mathrm{~b}$ & 20.0 \\
3 & 37.5 \\
4 & 62.5 \\
5 & 87.5 \\
\hline
\end{tabular}

5.0 package (Podani 1993). Similarities between the phytosociological relevés were calculated by means of Jaccard formula on the basis of presence or lack of compared species (Fig. 2).

For statistical purposes, the quantity level according to Braun-Blanquet scale was recalculated from the phytosociological table into the cover abundance scale (Table 1).

\section{Results}

Basing on the 21 phytosociological relevés, VeronicoMimuletum guttati association from the SparganioGlycerion fluitantis alliance was distinquished. The association which has not been observed so far in the territory of Pomerania or Poland appears at the rank of V-M.g. cardaminetosum amarae sub-association (Table $2)$. The characteristic species is clearly dominant in patches of Veronico-Mimuletum guttati. Veronica beccabunga co-dominates and occurs in all the relevés with another neophyte invading river habitats - Impatiens glandulifera. Also frequent were: Glyceria fluitans, 
Galium palustre, Ranunculus repens, Carex rostrata and C. paniculata. It was internally differentiated into two variants: a) spring variant found in spring areas (Table 2 , rel. 1-5), b) typical variant recorded in banks of rivers, ditches and water-logged meadows (Table 2, rel. 6-21). Small $\left(1-16 \mathrm{~m}^{2}\right)$ patches of the typical variant appeared in the river valleys of the Dębica, Grabowa, Parsęta and Rakówka rivers and smaller effluents: the Bliska Struga River and the Charbrowska Struga River as well as at productive exudations in girdling ditches and waterflows

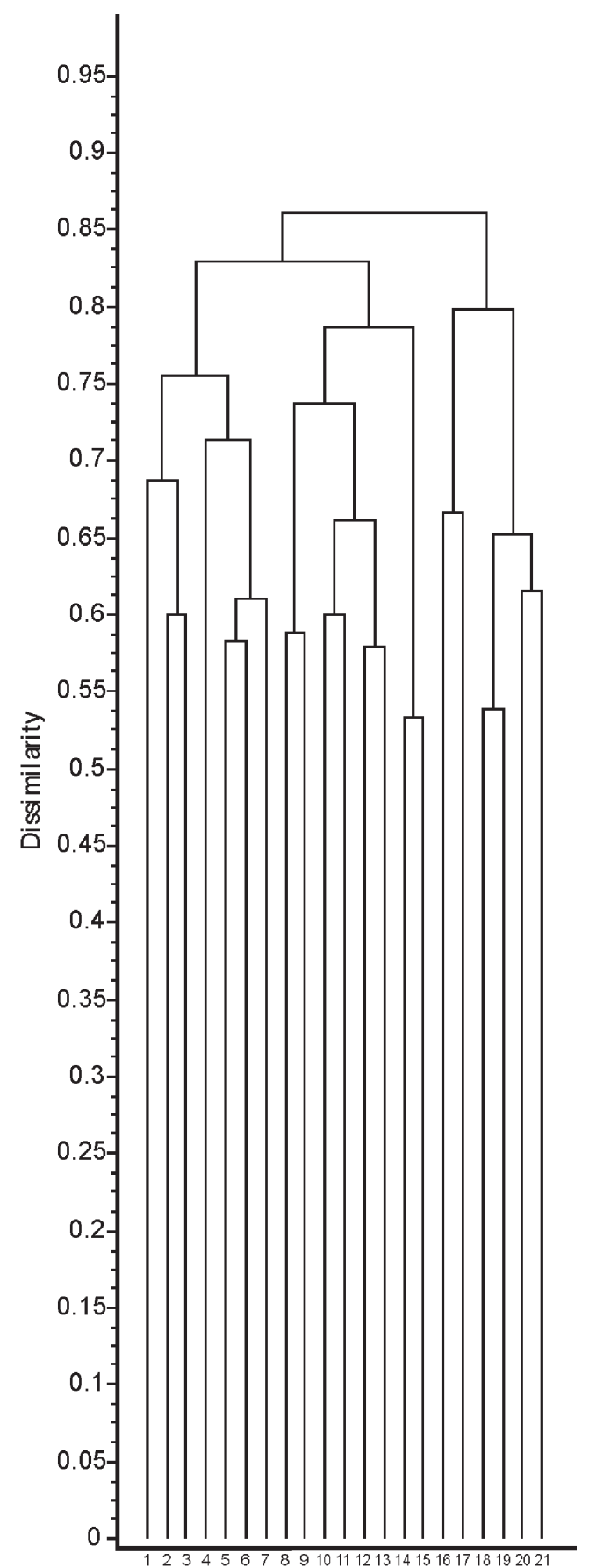

Fig 2. Classification of Veronico-Mimuletum guttati based on species composition in accordance with Jaccard's formula using the NCLAS program at peatbogs in the catchment of the Słupia River. Small as to its area, patches of the spring fen origin $\left(2-8 \mathrm{~m}^{2}\right)$ were found in the spring fens of the Łupawa River catchment and the outflows from spring fens of the Grabowa River catchment (Osadowski 2010).

The spring variant was florally poor (26 taxa) with dominating characteristic species: Mimulus guttatus and Cardamine amara subsp. amara. In individual patches, there were from 6 to 12 species (average 9). The moss layer was poorly developed. Only Brachythecium rivulare is worth mentioning, which appeared in the II stability class with a relatively high coverage ratio ( $\mathrm{D}=76$ ). Participation of Cratoneuron filicinum - moss characteristic for Montio-Cardaminetea class, was scarce. Stellaria uliginosa, which often formed dense patches of numerous procumbent shoots produced through vegetative propagation, was noted in the marshy substrate and sites of mineral-organic accumulation. In the headwater variant, patches developing along the groundwater runoff were characterised by the presence of Lemna minor, Myosotis palustris, and Mentha aquatica. The occurrence of Urtica dioica was associated with the substantially higher proportion of biogens in the organic accumulation sites.

The typical variant was florally rich (69 taxa). The number of species in phytocenoses of variants ranged between 6-31 (average 19). This variant occupied ditches and banks of streams. It was characterized by species composition from Artemisieta vulgaris (e.g. Urtica dioica), Bidentetea tripartiti (e.g. Polygonum hydropiper, Rorippa palustris) and Isoëto-Nanojuncetea (e.g. Plantago intermedia, Juncus bufonius, Gnaphalium uliginosum) classes. A numerous group (35 species) comprised sporadic taxons (occurring only in I constancy class).

\section{Discussion}

In Europe, especially in Western Europe, many species of the monkeyflower genus were cultivated as decorative plants (Stace 1997). Mimulus guttatus is a characteristic species of the Sparganio-Glycerietum fluitantis (Matuszkiewicz 2001) association. Kwiatkowski (2003) described, for the first time for Poland, the Veronico beccabungae -Mimuletum guttati association from the Sudety Zachodnie Mts.

The first information about the Veronico-Mimuletum guttati association originates from Germany, where Niemann (1965) provided its characteristics from the river valley of Thuringia. In the later period, it was reported several times in Germany and the Czech Republic (Galunder \& Patzke 1989; Koch 1991; Blažková 1999; Jehlik 2000; Rennwald 2000; Korsch et al. 2002; Waesch 2003; Springer 2006). Differences and similarities between selected forms of the association 
Table. 2. Veronico-Mimuletum guttati Niemann 1965 cardaminetosum amarae Osadowski, Sobisz, Truchan 2014 subass. nova. Nomenclature type: Table 2 rel. 7 (orig.) holotypus hoc loco (Niemann 1965; 429-432)

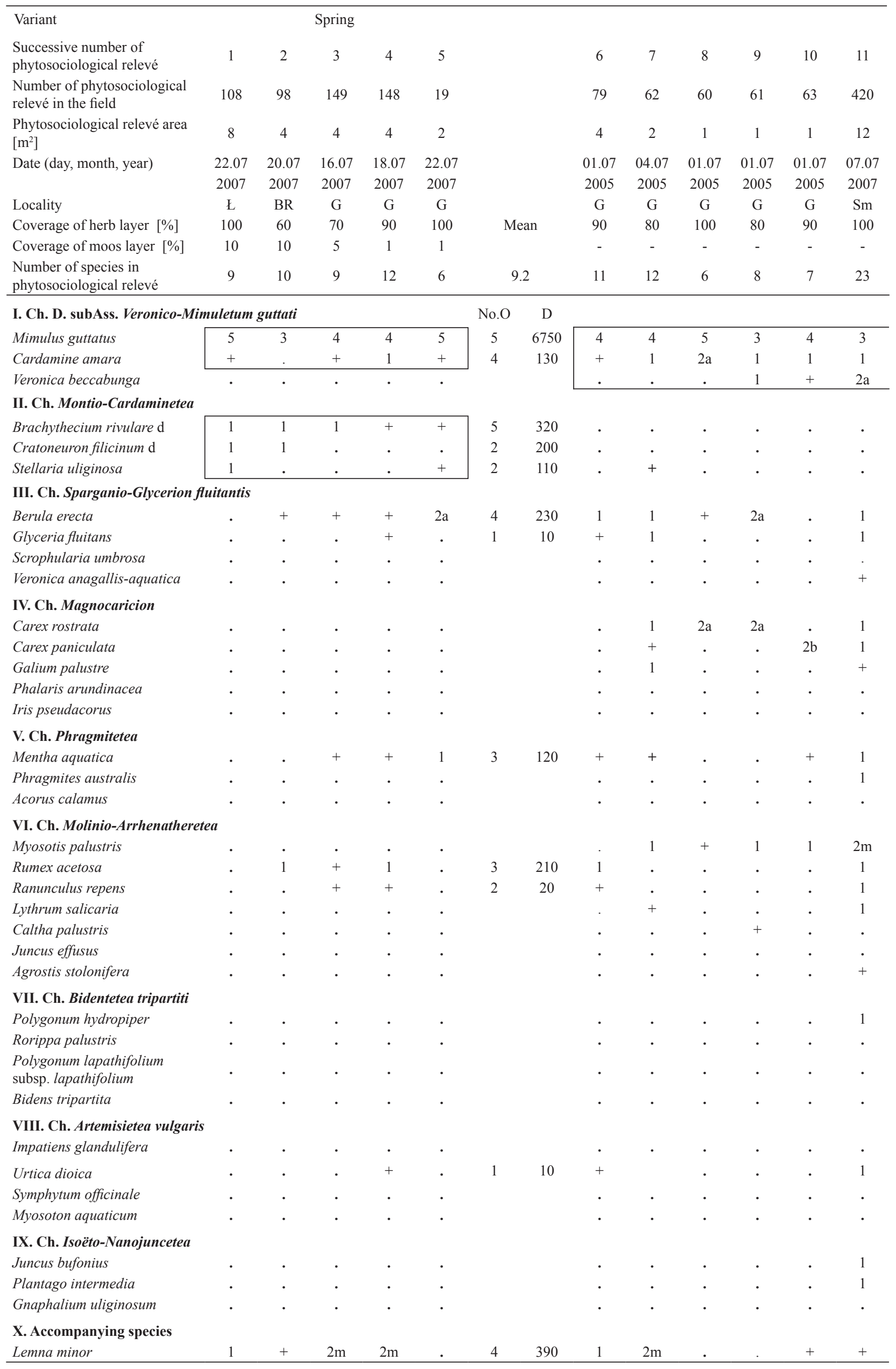


Typical

\begin{tabular}{|c|c|c|c|c|c|c|c|c|c|c|c|}
\hline 12 & 13 & 14 & 15 & 16 & 17 & 18 & 19 & 20 & 21 & & \\
\hline 654 & 221 & 367 & 605 & 611 & 538 & 334 & 238 & 589 & 658 & & \\
\hline 8 & 15 & 6 & 10 & 8 & 12 & 8 & 16 & 20 & 6 & & \\
\hline 09.08 & 12.07 & 02.07 & 23.07 & 23.07 & 12.07 & 28.06 & 19.07 & 29.06 & 09.08 & & \\
\hline 2014 & 2006 & 2005 & 2013 & 2013 & 2011 & 2005 & 2006 & 2012 & 2014 & \multirow{4}{*}{\multicolumn{2}{|c|}{ Mean }} \\
\hline L & Po & $\mathrm{Pa}$ & $\mathrm{Og}$ & $\mathrm{Si}$ & $\mathrm{Pk}$ & $\mathrm{Ch}$ & Łę & Łą & St & & \\
\hline 100 & 100 & 95 & 100 & 95 & 85 & 100 & 65 & 70 & 100 & & \\
\hline- & - & - & - & - & - & 1 & - & - & - & & \\
\hline 29 & 28 & 29 & 22 & 27 & 31 & 28 & 19 & 17 & 18 & \multicolumn{2}{|c|}{19.7} \\
\hline & & & & & & & & & & $\mathrm{S}$ & $\mathrm{D}$ \\
\hline 3 & 4 & 4 & 4 & 4 & 3 & 4 & 3 & 4 & 5 & V & 5781 \\
\hline 1 & 1 & + & + & 1 & 1 & 1 & 1 & + & . & V & 388 \\
\hline+ & . & + & . & 1 & 1 & . & . & . & . & III & 166 \\
\hline
\end{tabular}

Species occuring only in I constancy class: III. Carex gracilis 14 (1), 18,19(+), Lysimachia thyrsiflora $14(+)$, Scutellaria galericulata 12 $(+)$, IV. Equisetum fluviatile 17,18 (+), Sparganium erectum $15(1), 17,18(+), \mathbf{V I}$. Achillea ptarmica 13, 14, $17(+)$, Epilobium palustre 1, 4, 6, 8 (+), Equisteum palustre 2 (1), 3, 4, 6 $(+)$, Filipendula ulmaria 18, $19(+)$, Galium uliginosum $12(+)$, Juncus conglomeratus 20 $(+)$ Lotus uliginosus $20(+)$, Lysimachia nummularia $20(+)$, Lysimachia vulgaris 17 (1), $18(+)$, Odontites serotina $21(+)$, Potentilla anserina $21(+)$, Ranunculus acris $2(+)$, Scirpus sylvaticus 16, $21(+), 17$ (1), VII. Bidens frondosa $12(+)$, VIII. Artemisia vulgaris 14 $(+), 15(+)$, Chenopodium album 16(1), 17, 18 $(+)$, Cirsium arvense 13, 14, $17(+)$, Epilobium hirsutum $14(1), 18,19(+)$, E. parviflorum $1(+)$, Galeopsis speciosa $11(+)$, Melandrium album $21(+)$, Melilotus alba 11, $12(+)$, Rumex obtusifolius $1(+)$, Tanacetum vulgare 16, 17, $20(+)$, X. Dryopteris carthusiana 2, $13(+)$, Lycopus europaeus $19(+)$, Mnium hornum d 2, $19(+)$, Poa аппиа $21(+)$, Polygonum persicaria 20 $(+)$, Solanum dulcamara $21(+)$

Explanations: $\mathrm{BR}$ - Broczyna, $\mathrm{Ch}-\mathrm{Char}-$ browo, G - Gogolewko, L - Leszczyce, $\mathrm{E}$ - Łupawa, Ła - Łakowo, Łe - Łętowo, Og - Ogartowo, Pa - Paprotki, Pk - Popielewko, Po - Pomiłowo, Si - Sińce, Sm - Smołdzino, $\mathrm{St}$ - Stojcino; No.O - number of occurrence, S - phytosociological stability, D - cover coefficient 
Table 3. Floristic differentiation of Veronico-Mimuletum guttati Niemann 1965 in Central Europa

\begin{tabular}{|c|c|c|c|c|c|c|}
\hline References/Source & A & $\mathrm{B}$ & $\mathrm{C}$ & $\mathrm{D}$ & E1 & E2 \\
\hline Number of phytosociological relevés & 15 & 5 & 10 & 12 & 5 & 16 \\
\hline Number of species in phytosociological relevé & 52 & 27 & 48 & 66 & 12 & 54 \\
\hline \multicolumn{7}{|l|}{ Ch. Veronico-Mimuletum guttati } \\
\hline Mimulus guttatus & $\mathrm{V}^{+-4}$ & $5^{+-5}$ & $\mathrm{~V}^{+-5}$ & $\mathrm{~V}^{1-5}$ & $5^{+-5}$ & $\mathrm{~V}^{3-5}$ \\
\hline Veronica beccabunga & $\mathrm{IV}^{+-4}$ & . & . & $\mathrm{III}^{+-2}$ & . & $\mathrm{III}^{+-2}$ \\
\hline Epilobium roseum* & $\mathrm{III}^{+-2}$ & . & . & $\mathrm{III}^{+-2}$ & . & . \\
\hline Cardamine amara* & $\mathrm{III}^{+-2}$ & . & $\mathrm{II}^{+-2}$ & . & $4^{+-2}$ & $\mathrm{III}^{+-2}$ \\
\hline \multicolumn{7}{|l|}{ Ch. Sparganio-Glycerion fluitantis } \\
\hline Glyceria fluitans & $\mathrm{IV}^{+-4}$ & $1^{+}$ & $\mathrm{II}^{+-1}$ & $\mathrm{III}^{+-1}$ & $1^{+}$ & $\mathrm{III}^{+-2}$ \\
\hline Nasturtium officinalis & $\mathrm{I}^{+-4}$ & . & . & $\mathrm{I}^{+}$ & . & . \\
\hline Veronica anagallis-aquatica & $\mathrm{I}^{+}$ & . & . & . & . & $\mathrm{II}^{+-1}$ \\
\hline Scrophularia umbrosa & . & . & $\mathrm{I}^{+}$ & $\mathrm{II}^{+}$ & . & $\mathrm{II}^{+-2}$ \\
\hline Leersia oryzoides & . & . & $\mathrm{I}^{+}$ & . & . & . \\
\hline Berula erecta & . & . & . & . & $4^{+-1}$ & $\mathrm{IV}^{+-2}$ \\
\hline \multicolumn{7}{|l|}{ Ch. Montio-Cardaminetea } \\
\hline Brachythecium rivulare d & . & . & . & . & $5^{+-1}$ & . \\
\hline Stellaria uliginosa & . & . & . & . & $2^{+-1}$ & . \\
\hline Cratoneurion filicinumd & . & . & . & . & $2^{1}$ & . \\
\hline \multicolumn{7}{|l|}{ Ch. Magnocaricion } \\
\hline Phalaris arundinacea & $\mathrm{II}^{+}$ & . & $\mathrm{III}^{+-1}$ & $\mathrm{II}^{+-1}$ & . & $\mathrm{II}^{+-1}$ \\
\hline Galium palustre & $\mathrm{IV}^{+-4}$ & . & . & $\mathrm{I}^{+}$ & . & $\mathrm{III}^{+-1}$ \\
\hline Carex gracilis & $\mathrm{I}^{+}$ & . & . & $\mathrm{I}^{+}$ & . & $\mathrm{I}^{+-1}$ \\
\hline Iris pseudacorus & $\mathrm{I}^{+}$ & . & . & $\mathrm{I}^{+}$ & . & $\mathrm{II}^{+-1}$ \\
\hline Poa palustris & . & $2^{+-1}$ & . & $\mathrm{II}^{+-1}$ & . & . \\
\hline Carex rostrata & $\mathrm{I}^{+}$ & . & . & . & . & $\mathrm{IV}^{+-2}$ \\
\hline Carex paniculata & . & . & . & . & . & $\mathrm{III}^{+-2}$ \\
\hline Lysimachia thyrsiflora & . & . & . & . & . & $\mathrm{I}^{+}$ \\
\hline Scutellaria galericulata & . & . & . & . & . & $\mathrm{I}^{+}$ \\
\hline \multicolumn{7}{|l|}{ Ch. Phragmitetea } \\
\hline Eleocharis palustris & $\mathrm{I}^{+-2}$ & . & . & $\mathrm{I}^{+}$ & . & . \\
\hline Rorripa amphibia & . & . & $\mathrm{I}^{+}$ & $\mathrm{I}^{+-2}$ & . & . \\
\hline Equisetum fluviatile & $\mathrm{I}^{+}$ & . & . & . & . & $\mathrm{I}^{+}$ \\
\hline Alisma plantago-aquatica & $\mathrm{I}^{+}$ & . & . & . & . & . \\
\hline Acorus calamus & . & . & . & $\mathrm{II}^{+-1}$ & . & $\mathrm{II}^{+-1}$ \\
\hline Sparganium erectum & . & . & . & $\mathrm{I}^{+-2}$ & . & $\mathrm{I}^{+-1}$ \\
\hline Phragmites australis & . & . & . & $\mathrm{I}^{+-2}$ & . & $\mathrm{III}^{+-1}$ \\
\hline Mentha aquatica & . & . & . & . & $3^{+-1}$ & $\mathrm{IV}^{+-1}$ \\
\hline \multicolumn{7}{|l|}{ Ch. Molinio-Arrhenatheretea } \\
\hline Ranunculus repens & $\mathrm{IV}^{+-2}$ & . & $\mathrm{II}^{+-2}$ & $\mathrm{I}^{+}$ & $2^{+}$ & $\mathrm{III}^{+-1}$ \\
\hline Myosotis palustris & $\mathrm{II}^{+-1}$ & $3^{+-1}$ & $\mathrm{II}^{+-1}$ & $\mathrm{IV}^{+-4}$ & . & $\mathrm{IV}^{+-2}$ \\
\hline Agrostis stolonifera & $\mathrm{I}^{+}$ & $1^{+}$ & . & $\mathrm{III}^{+-3}$ & . & $\mathrm{II}^{+}$ \\
\hline Juncus effusus & $\mathrm{I}^{+}$ & $5^{+-1}$ & . & $\mathrm{I}^{+}$ & . & $\mathrm{II}^{+-1}$ \\
\hline Achillea ptarmica & $\mathrm{II}^{+-1}$ & . & . & $\mathrm{I}^{+}$ & . & $\mathrm{I}^{+}$ \\
\hline Galium uliginosum & $\mathrm{II}^{+-1}$ & . & . & $\mathrm{I}^{+}$ & . & $\mathrm{I}^{+}$ \\
\hline Lysimachia nummularia & $\mathrm{I}^{+}$ & . & . & $\mathrm{I}^{+}$ & . & $\mathrm{I}^{+}$ \\
\hline Lythrum salicaria & . & . & $\mathrm{I}^{+}$ & $\mathrm{I}^{+-2}$ & . & $\mathrm{II}^{+-1}$ \\
\hline Lotus uliginosus & $\mathrm{IV}^{1-2}$ & . & . & . & . & $\mathrm{I}^{+}$ \\
\hline Equisetum palustre & $\mathrm{I}^{+}$ & . & . & . & . & $\mathrm{I}^{+-1}$ \\
\hline Caltha palustris & $\mathrm{I}^{+-2}$ & . & . & . & . & $\mathrm{II}^{+-1}$ \\
\hline Juncus conglomeratus & $\mathrm{I}^{+-2}$ & . & . & . & . & $\mathrm{I}^{+}$ \\
\hline Filipendula ulmaria & $\mathrm{I}^{+-2}$ & . & . & . & . & $\mathrm{I}^{+}$ \\
\hline Scirpus sylvaticus & $\mathrm{I}^{+}$ & . & . & . & . & $\mathrm{I}^{+-1}$ \\
\hline Rumex acetosa & . & . & . & . & $3^{+-1}$ & $\mathrm{III}^{+-2}$ \\
\hline Lysimachia vulgaris & . & . & . & . & . & $\mathrm{I}^{+-1}$ \\
\hline Potentilla anserina & . & . & . & . & . & $\mathrm{I}^{+}$ \\
\hline Ranunculus acris & . & . & . & . & . & $\mathrm{I}^{+}$ \\
\hline Epilobium palustre & . & . & . & . & . & $\mathrm{I}^{+}$ \\
\hline
\end{tabular}


References/Source

Number of phytosociological relevés

Number of species in phytosociological relevé

Odontites serotina

Sanguisorba officinalis

Ch. Bidentetea tripartiti

Polygonum hydropiper

Rorippa palustris

Polygonum lapathifolium subsp. lapathifolium

Bidens tripartita

Bidens frondosa

Rumex maritimus

Bidens radiata

Alopecurus aequalis

Bidens cernua

Ranunculus sceleratus

\begin{tabular}{|c|c|c|c|c|c|}
\hline A & B & $\mathrm{C}$ & $\mathrm{D}$ & E1 & E2 \\
\hline 15 & 5 & 10 & 12 & 5 & 16 \\
\hline 52 & 27 & 48 & 66 & 12 & 54 \\
\hline . & . & . & . & . & $\mathrm{I}^{+}$ \\
\hline . & . & . & $\mathrm{I}^{+}$ & . & . \\
\hline . & $5^{1-2}$ & $\mathrm{II}^{+-1}$ & $\mathrm{I}^{+-2}$ & . & $\mathrm{III}^{+-1}$ \\
\hline . & $5^{+-2}$ & $\mathrm{II}^{+}$ & $\mathrm{V}^{+-4}$ & . & $\mathrm{III}^{+-1}$ \\
\hline . & $1^{+}$ & $\mathrm{II}^{+-1}$ & $\mathrm{~V}^{+-3}$ & . & $\mathrm{II}^{+}$ \\
\hline . & . & . & $\mathrm{IV}^{+-4}$ & . & $\mathrm{II}^{+}$ \\
\hline . & . & $\mathrm{IV}^{+-3}$ & . & . & $\mathrm{I}^{+}$ \\
\hline . & . & $\mathrm{I}^{+}$ & . & . & . \\
\hline & $2^{+}$ & . & . & & . \\
\hline . & . & . & $\mathrm{II}^{+-1}$ & . & . \\
\hline . & . & . & $\mathrm{I}^{+}$ & . & . \\
\hline . & . & . & $\mathrm{I}^{+}$ & . & . \\
\hline $\mathrm{II}^{+}$ & $2^{+}$ & $\mathrm{II}^{+-1}$ & $\mathrm{I}^{+}$ & . & $\mathrm{I}^{+}$ \\
\hline II ${ }^{+-1}$ & . & $\mathrm{II}^{+-1}$ & $\mathrm{III}^{+-1}$ & . & . \\
\hline . & . & $\mathrm{IV}^{+-2}$ & $\mathrm{I}^{+}$ & $1^{+}$ & $\mathrm{III}^{+-1}$ \\
\hline . & . & $\mathrm{II}^{+-1}$ & $\mathrm{I}^{+}$ & . & $\mathrm{I}^{+-1}$ \\
\hline . & . & $\mathrm{I}^{+}$ & $\mathrm{II}^{+-1}$ & . & $\mathrm{I}^{+}$ \\
\hline . & . & $\mathrm{I}^{+-2}$ & $\mathrm{I}^{+-1}$ & . & $\mathrm{I}^{+}$ \\
\hline . & . & $\mathrm{I}^{+-2}$ & $\mathrm{II}^{+}$ & . & $\mathrm{II}^{+-1}$ \\
\hline . & . & $\mathrm{I}^{+}$ & $\mathrm{I}^{+}$ & . & $\mathrm{I}^{+-1}$ \\
\hline . & $1^{+}$ & . & $\mathrm{I}^{+}$ & . & . \\
\hline . & . & $\mathrm{I}^{+}$ & . & . & . \\
\hline . & . & $\mathrm{I}^{+}$ & . & . & $\mathrm{I}^{+-1}$ \\
\hline . & . & $\mathrm{I}^{+}$ & $\mathrm{IV}^{+-2}$ & . & $\mathrm{I}^{+-1}$ \\
\hline . & . & . & $\mathrm{II}^{+-1}$ & . & $\mathrm{II}^{+-1}$ \\
\hline . & . & . & . & . & $\mathrm{III}^{+-1}$ \\
\hline . & . & . & . & . & $\mathrm{I}^{+-1}$ \\
\hline . & . & . & . & . & $\mathrm{I}^{+}$ \\
\hline . & . & . & . & . & $\mathrm{I}^{+}$ \\
\hline . & . & . & $\mathrm{I}^{+}$ & . & . \\
\hline . & . & . & $\mathrm{I}^{+}$ & . & . \\
\hline . & . & . & $\mathrm{I}^{+}$ & . & . \\
\hline . & $1^{+}$ & $\mathrm{II}^{+-2}$ & $\mathrm{I}^{+}$ & . & $\mathrm{II}^{+-1}$ \\
\hline . & $5^{+-2}$ & $\mathrm{I}^{+}$ & $\mathrm{I}^{+}$ & . & $\mathrm{III}^{+-1}$ \\
\hline . & $5^{+-2}$ & . & $\mathrm{IV}^{+-2}$ & . & $\mathrm{II}^{+}$ \\
\hline . & $1^{+}$ & . & $\mathrm{I}^{+}$ & . & . \\
\hline $\mathrm{I}^{+-2}$ & . & $\mathrm{I}^{+}$ & . & . & . \\
\hline $\mathrm{I}^{+}$ & . & . & $\mathrm{I}^{+}$ & . & . \\
\hline $\mathrm{II}^{+}$ & . & . & $\mathrm{I}^{+}$ & . & . \\
\hline . & $2^{+-2}$ & $\mathrm{II}^{+-2}$ & . & . & $\mathrm{I}^{+}$ \\
\hline . & $1^{+}$ & $\mathrm{I}^{+}$ & . & . & $\mathrm{I}^{+}$ \\
\hline . & . & . & $\mathrm{III}^{+-2}$ & . & $\mathrm{I}^{+}$ \\
\hline . & . & . & . & $4^{+-2}$ & $\mathrm{IV}^{+-2}$ \\
\hline . & . & . & . & . & $\mathrm{I}^{+}$ \\
\hline . & . & . & . & . & $\mathrm{I}^{+}$ \\
\hline . & . & . & . & . & $\mathrm{I}^{+}$ \\
\hline 20 & 9 & 18 & 15 & 14 & 15 \\
\hline
\end{tabular}

\section{Ch. Artemisietea vulgaris}

Rumex obtusifolius

Mentha longifolia

Urtica dioica

Epilobium hirsutum

Tanacetum vulgare

Artemisia vulgaris

Symphytum officinale

Chenopodium album

Capsella bursa-pastoris

Calystegia sepium

Cirsium arvense

Melilotus alba

Myosoton aquaticum

Impatiens glandulifera

Galeopsis speciosa

Epilobium parviflorum

Melandrium album

Saponaria officinalis

Barbarea vulgaris

Senecio viscosus

Ch. Isoëto-Nanojuncetea

Plantago intermedia

Juncus bufonius

Gnaphalium uliginosum

Limosella aquatica

Accompanying species

Poa trivialis

Holcus lanatus

Epilobium obscurum

Polygonum persicaria

Роа аппиа

Lycopus europaeus

Lemna minor

Dryopteris carthusiana

Mnium hornum d

Solanum dulcamara

Other accompanying species

Explanations: A - Niemann E. 1965, B - Galunder R. \& Patzke E. 1989, C - Blažková D. 1999, D - Kwiatkowski P. 2003, E Sobisz Z., Osadowski Z., Truchan M. 2014 (unpubl.), 1 - spring variant, 2 - typical variant 
are presented in Table 3. In each case, Mimulus guttatus was provided as a species characteristic for the association under consideration. Moreover, in patches of the association, species from the remaining syntaxa were noted: Glyceria fluitans, Myosotis palustris and Rumex obtusifolius. The differences refer to participation of some species or ecological groups. In Niemann's material (1965) Galium palustre, Lotus uliginosus appear more often, especially the meadow plants of the Molinietalia order, and there is a complete lack of the species of Bidentetea tripartiti and Isoëto-Nanojuncetea classes. The comparison of the forms of the association from the river valleys of Hessia (Galunder \& Patzke 1989) with the material of the authors from the river basin of the Parsęta River and the Stupia River reveals a more important role of the species of riparian therophytes (Bidentetea tripartiti) and silt soil plants (Isoëto-Nanojuncetea). In the phytosociological relevés from the Bóbr River valley (Kwiatkowski 2003), a big participation of rushes taxa draws our attention from the connections of Sparganio-Glycerion fluitantis and Magnocaricion alliances as well as Phragmitetea and Artemisietea vulgaris classes. Similarly, floristic relationships were observed by the authors of the study. In the river valleys of the Grabowa River, the Łupawa River, the Rakówka River and minor waterflows, a larger number of species of the Molinietalia order was found. However, in the river valley of the Berounka River in the river basin of the Vltawa River (Blažková 1999), a minimum participation of the rushes species draws our attention and the increased presence of Bidens frondosa - a species not found in the forms from Germany or the Czech Republic. In Central Pomerania, the authors discovered it in the Stupia River valley and the valley of the Charbrowska Struga River. In Poland, it was recognized as an invasive species (Urbisz et al. 2009). Impatiens glandulifera found along the banks of the Bliska Struga River, the Rakówka River and the Stupia River, drainage ditches and land depressions on Łętowo Lake and Oparzno Lake has a similar status (Tokarska-Guzik et al. 2012). A comparison of the number of species in the syntaxonomic groups revealed an increased proportion of meadow species from the Molinio-Arrhenatheretea class, ruderal species from the Artemisietea vulgaris class, and rush species from the Magnocaricion alliance in the area of Pomerania (Table 4).

Data collected so far from European countries indicate a potential threat posed by competition from Mimulus guttatus and, in the area of dense patches, its impact on the species composition and structure of communities with Sparganio-Glycerion fluitantis (Tokarska-Guzik \& Dajdok 2010). This phenomenon seems to be of special importance in legally protected areas, in particular, in the Słowiński National Park (Piotrowska et al. 1997). The biological features of Mimulus guttatus promote efficient generative propagation of the species through highly germinable seeds and vegetative spread through fragments of rooting shoots and stolons (Truscott et al. 2006). The diversity of the habitat conditions in the headwater niches is reflected in their floristic diversity. The headwater areas are colonised by crenophytes, which tolerate the low temperature of spring waters. Plants inhabiting these areas may be highly specific to them or may also occur elsewhere. They include Berula erecta, an obligate crenophyte occurring exclusively in springs, and Carex paniculata and Scirpus sylvaticus, facultative crenophytes growing both in headwater areas and elsewhere.

\section{Conclusions}

- A subassociation of Veronico-Mimuletum guttati cardaminetosum amarae, unknown so far, was dis-

Table 4. Number of species in each syntaxonomic group of the association Veronico-Mimuletum guttati Niemann 1965 in Central Europe

\begin{tabular}{lcccccc}
\hline References/Source & A & B & C & D & \multicolumn{2}{c}{ E } \\
Number of phytosociological relevés & 15 & 5 & 10 & 12 & 5 & 16 \\
Number of species in phytosociological relevé & 52 & 27 & 48 & 66 & 12 & 54 \\
\hline Ch. Veronico-Mimuletum guttati & 4 & 1 & 2 & 3 & 2 & 3 \\
Ch. Sparganio-Glycerion fluitantis & 3 & 1 & 3 & 3 & 2 & 4 \\
Ch. Montio-Cardaminetea &. &. &. &. & 3 &. \\
Ch. Magnocaricion & 5 & 1 & 1 & 5 &. & 8 \\
Ch. Phragmitetea & 3 &. & 1 & 5 & 1 & 5 \\
Ch. Molinio-Arrhenatheterea & 10 & 2 & 2 & 5 &. & 15 \\
Ch. Bidentetea tripartiti &. & 4 & 5 & 7 &. & 5 \\
Ch. Artemisietea vulgaris & 10 & 2 & 2 & 5 &. & 15 \\
Ch. Isoëto-Nanojuncetea &. & 4 & 2 & 4 &. & 3 \\
Accompanying species & 6 & 3 & 4 & 6 & 3 & 12 \\
Other accompanying species & 20 & 9 & 18 & 15 & 14 & 15 \\
\hline
\end{tabular}


tinguished. The said subassociation is characterized by a very high participation of Mimulus guttatus and Cardamine amara subsp. amara.

- Veronico-Mimuletum guttati is a member of the Sparganio-Glycerion fluitantis alliance. Sometimes, the species occurs in phytocoenoses of other communities of the Phragmitetea, Bidentetea tripartiti and Isoëto-Nanojuncetea classes.

- Within the V-M.g. cardaminetosum amarae subassociation, two variants were distinguished: spring fen and typical variants. The spring fen variant is characterized by a constant presence of Cardamine amara subsp. amara and other characteristic species for the Montio-Cardaminetea class. Participation of the monkeyflower in the group of spring fen associations indicates that it is a good phytoindicator of the increased levels of biogenic substances in outflows.
- The analysis of similarities between the selected forms of the association from Central Europe revealed a constant share of the characteristic species Mimulus guttattus and Veronica beccabunga and occurrence of species representing the other syntaxa, i.e. Glyceria fluitans, Myosotis palustris, and Rumex obtusifolius, in the patches of the association. The differences were visible in the share of some species or syntaxonomic groups with the notably increased proportion of meadow species from the MolinioArrhenatheretea class, ruderal species from the Artemisietea vulgaris class, and rush species from the Magnocaricion alliance.

- Establishment of a possible scale of variability of that association requires constant monitoring and analysis of richer phytosociological materials, especially in the remaining part of Pomerania.

\section{References}

BlažKovÁ D. 1999. Kejklírka skvnitá (Mimulus guttatus DC.) na Všenorskéem potoce a $\mathrm{v}$ údoli Berounky. Muz. Souč. Roztoky, Ser. Natur. 13: 63-68.

Braun-Blanquet J. 1951. Pflanzensoziologie. Grundzüge der Vegetationskunde. 631 pp. Springer Verlag, Wien.

Galunder R. \& Patzke E. 1989. Soziologische Bemerkungen zu Vorkommen von Mimulus guttatus an Talsperren des Süderbergland. Tüxenia 9: 55-56.

Hennekens S. M. \& Schaminée J. H. J. 2001. TURBOVEG, a comprehensive database management system for vegetation data. J. Veg. Sci. 12: 589-591.

Holzfuss E. 1937. Beitrag zur Adventivflora von Pommern. Dohriana 16: 94-130.

Hultén E. \& Fries M. 1986. Atlas of North European Vascular Plants. North of the Tropic of Cancer. I. Introduction, taxonomic index to the maps 1-996. Maps 1-996. xvi+498 pp. Koeltz Scientific Books, Königstein.

JенLik V. 2000. Die neophytische Gesellschaft Veronico beccabungae-Mimuletum guttati (Sparganio-Glycerion fluitantis - Verband) auch im Böhmerwald. Silva Gabreta 5: 93-102.

Kondracki J. 2004. Geografia regionalna Polski. 441 pp. PWN Warszawa.

Косн M. 1991. Zur Kenntnis von Juncus ensifolius Wikström 1823. Ein Neufund aus dem Südkreis von Osnabrück. Osnabrücker Naturwiss. Mitt. 17: 171-173.

Korsch H., Westhus W. \& ZÜNDORF H. J. 2002. Verbreitungsatlas der Farn- und Blütenpflanzen Thüringens. 419 pp. Weissdorn-Verlag, Jena.

Kwiatkowski P. 2003. Zespół Veronico beccabungae-Mimuletum guttati w dolinie Bobru (Sudety Zachodnie). Przyroda Sudetów Zachodnich 6: 59-66

Lohmeyer W. \& Sukopp H. 1992. Agriophytes in der Vegetation Mitteleuropas. Schriftenreihe für Vegetationskunde 25: 1-185.
Matuszkiewicz W. 2001. Przewodnik do oznaczania zbiorowisk roślinnych Polski. In: J. B. FALıŃSKi (ed.). Vademecum Geobotanicum 3, 537 pp. Wyd. Nauk. PWN, Warszawa.

Meusel H., Jäger E., Rauschert S. \& Weinert E. 1978. Vergleichende Chorologie der zentraleuropäischen Flora. II. Text xi+418 pp., Karten pp. 259-421. Gustav Fischer Verlag, Jena.

Mirek Z., Piękoś-Mirkowa H., Zając A. \& Zając M. 2002. Flowering plants and pteridophytes of Poland. A checklist. In: Z. MireK (ed.). Biodiversity of Poland, 1, 442 pp. W. Szafer Institute of Botany, Polish Academy of Sciences, Kraków.

Misiewicz J. 1977. Nieznane zbiory zielnikowe flory Pomorza zachowane w muzuem w Darłowie. In: E. R. Śpiewakowski \& M. Kalfus (eds.). Ochrona i kształtowanie środowiska przyrodniczego Pomorza Środkowego, pp. 195-226. Wyd. WSP, Słupsk.

Niemann E. 1965. Submontane und montane flussbegleitende Glanzgrass-Röhrichte in Thüringen und ihre Beziehungen zu den hydrologischen Verhältnissen. Limnologica 3: 399-438.

Oberdorfer E. 2001. Pflanzensoziologische Exkursionflora für Deutschland und angrenzende Gebiete. 8 Aufl., 1051 pp. Verl. Eugen Ulmer, Stuttgart.

Ochyra R., Żarnowiec J. \& Bednarek-Ochyra H. 2003. Census Catalogue of Polish Mosses. In: Z. Mirek (ed.). Biodiversity of Poland, 3, 372 pp. Polish Academy of Sciences, Institute of Botany, Kraków.

OsADOwsKi Z. 2010. Wpływ uwarunkowań hydrologicznych i hydrochemicznych na zróżnicowanie szaty roślinnej źródlisk w krajobrazie młodoglacjalnym Pomorza. 198 pp. Bogucki Wyd. Nauk., Poznań-Słupsk.

PAwŁowski B. 1977. Skład i budowa zbiorowisk roślinnych oraz metody ich badania. In: W. SzAFER \& K. ZARZYCKI 
(eds.). Szata roślinna Polski, I, wyd. 3, pp. 237-269. PWN, Warszawa.

PIĘKoŚ H. 1972. Rodzaj Mimulus L. w Polsce. Fragm. Flor. Geobot. 18(3-4): 343-351.

Piotrowska H., Żukowski W. \& Jackowiak B. 1997. Rośliny naczyniowe Słowińskiego Parku Narodowego. Prace Zakładu Taksonomii Roślin UAM w Poznaniu 6: 7-216.

Podani J. 1993. Syn-Tax - pc. Computer Programs for Multivare Data Analysis in Ecology and Systematics. Version 5.0. 351 pp. User's Giude. Scientia Publishing, Budapest.

RatyŃSka H., Wojterska M. \& Brzeg A. 2010. Multimedialna encyklopedia zbiorowisk roślinnych Polski. Narodowy Fundusz Ochrony Środowiska i Gospodarki Wodnej w Warszawie, CD 1-2.

RenNwald E. (ed.). 2000. Rote Liste der Pflanzengesellschaften Deutschlands mit Anmerkungen zur Gefährdung. In: E. RenNwALD (ed.). Verzeichnis und Rote Liste der Pflanzengesellschaften Deutschlands. Schriften Reihe f. Vegetationskunde 35: 393-592.

SLavíK B. 2000. Mimulus L. - kejklíŕka. In: B. StavíK (ed.). Květena České republiky 6: 320-324.

SPRINGER S. 2006. Die Vegetation des Landkreis Altötting in Bayern. Beitr. Naturk. Oberösterreichs 16: 223-434.

Stace C. A. 1997. New flora of the British Isles. 1130 pp. Cambridge Univ. Press, Cambridge.

TOKARSKA-GuZIK B. 2005. The Establishment and Spread of Alien Plant Species (Kenophytes) in the Flora of Po- land. Prace naukowe Uniw. Śląskiego w Katowicach 2372: 1-192.

TOKARSKA-GuZIK B. \& DAJdoK Z. 2010. NOBANIS - Invasive Alien Species Fact Sheet - Mimulus guttatus. From: Online Database of the Network on Invasive Alien Species - NOBANIS, www.nobanis.org, Date of access 20/03/2015.

ToKarsKa-GuZiK B., DAJdok Z., ZająC M., ZajĄC A., UrbisZ A., Danielewicz W. \& HoŁdyński C. 2012. Rośliny obcego pochodzenia w Polsce ze szczególnym uwzględnieniem gatunków inwazyjnych. 196 pp. NFOŚ i GW, Warszawa.

Truscott A-M., Soulsby C., Palmer S. C. F., Newell L. \& Hulme P. E. 2006. The dispersal characteristics of the invasive plant Mimulus guttatus and the ecological significance of increased occurrence of high-flow events. J. Ecol. 94: 1080-1091.

Urbisz Al., Urbisz An., BŁażyca B. \& Tokarska-GuziK B. 2009. Uczep amerykański Bidens frondosa L. In: Z. DAJDOK \& P. PAWLACZYK (ed.). Inwazyjne gatunki roślin ekosystemów mokradłowych Polski, pp. 52-53. Wyd. Klubu Przyrodników, Świebodzin.

WAEsch G. 2003. Montane Graslandvegetation des Thüringer Waldes: Aktueller Zustand, historische Analyse und Entwicklungsmöglichkeiten. 219 pp. Diss. Univ. Göttingen, Cuvillier Verlag.

ZAJĄC A. 1978. Atlas of distribution of vascular plants in Poland (ATPOL). Taxon 5/6: 481-484. 